\title{
PENGARUH DUKUNGAN SOSIAL DAN KELUARGA TERHADAP KUALITAS HIDUP PASIEN DM TIPE 2 DI WILAYAH KERJA PUSKESMAS MANGASA KOTA MAKASSAR
}

The Effect of Social and Family Support on the Quality of Life of Diabetes Mellitus Type 2 Patients in the Mangasa Health Center Makassar City.

\author{
Maryati Tombokan ${ }^{1}$, Muh. Ardi ${ }^{2}$, Novi Desriyani Syarif ${ }^{3}$ \\ Poltekkes Kemenkes Makassar \\ *) E-mail maryatitombokan@gmail.com \\ ardi@poltekkes-mks.ac.id \\ novidesriyani12@gmail.com
}

\begin{abstract}
Diabetes mellitus is an abnormality of insulin secretion, insulin action, or both of which are marked by an increase in blood glucose levels or hyperglycemia. Various problems caused by diabetes mellitus often make individuals experience excessive anxiety, this can affect the quality of life. The purpose of this study was to determine the effect of social and family support on the quality of life of patients with type 2 diabetes mellitus in the working area of Mangasa Health Center in Makassar City. The research method uses descriptive analytic with cross sectiona technique approach. The results of the study using unpaired $t$ test showed that there is a social influence sampling on quality of life $(p=0.02)$, and there is a family influence on quality of life $(p=0.01)$. The conclusion from the results of the study is that there is an influence of social and family support on the quality of life of patients with type 2 diabetes mellitus.
\end{abstract}

Keywords : Diabetes mellitus, social and family support, quality of life

\section{ABSTRAK}

Diabetes mellitus merupakan kelainan sekresi insulin, kerja insulin, atau keduanya yang ditandai dengan kenaikan kadar glukosa darah atau hiperglikemia. Berbagai masalah yang disebabkan oleh diabetes mellitus seringkali membuat individu mengalami kecemasan yang berlebihan, hal ini dapat mempengaruhi kualtas hidupnya. Tujuan penelitian untuk mengetahui pengaruh dukungan sosial dan keluarga terhadap kualitas hidup pasien diabete mellitus tipe 2 di wilayah kerja Puskesmas Mangasa Kota Makassar. Metode penelitian menggunakan descriptive analytic dengan pendekatan cross sectional. Hasil penelitian dengan menggunakan uji $t$ tidak berpasangan menunjukkan bahwa ada pengaruh dukungan sosial terhadap kualitas hidup $(p=0,02)$, dan ada pengaruh dukungan keluarga terhadap kualitas hidup $(p=0,01)$. Kesimpulan dari hasil penelitian ini adalah ada pengaruh dukungan sosial dan keluarga terhadap kualitas hidup pasien diabetes mellitus tipe 2.

Kata kunci : Diabetes mellitus, dukungan sosial dan keluarga, kualitas hidup

\section{PENDAHULUAN}

Penyakit diabetes mellitus merupakan sekelompok kelainan heterogen yang ditandai dengann kenaikan kadar glukosa darah atau hiperglikemia yang terjadi karena kelainan sekresi insulin, kerja insulin,atau keduanya (Mirza et al, 2017). Data dari WHO (World Health Organization) (2016) menujukkan bahwa " pada tahun 2015 jumlah penderita sebanyak 415 juta jiwa dan akan mengalami meningkatan pada tahun 2040 sebanyak 642 juta jiwa". Angka penderita diabetes pada orang dewasa di wilayah regional Asia Tenggara mengalami peningkatan pada tahun 1980an sebanyak 4,1\% menjadi 8,6\% di tahun 2014 (WHO, 2016).

Prevalensi diabetes se-Indonesia menurut Kemenkes RI (2014) diduduki oleh provinsi Jawa Timur. Data Dinas Kesehatan Kota Makassar (2015) menyatakan bahwa kasus DM di Provinsi Sulawesi
Selatan, usia di atas 15 tahun berada diurutan ke-3, meningkat dari $0,8 \%$ menjadi $3,4 \%$, dengan peningkatan yang paling besar yaitu sebesar $2,6 \%$. Angka kejadian penyakit diabetes mellitus pada tahun 2011 yaitu 5700 kasus, tahun 2012 meningkat menjadi 14.067 kasus, tahun 2013 menjadi 14.604 kasus, semakin meningkat di tahun 2014 menjadi 21.452 kasus.

Data yang diperoleh dari Puskesmas Mangasa menunjukkan adanya peningkatan kunjungan pasien diabetes mellitus dari tahun ke tahun. Pada tahun 2016, jumlah kunjungan pasien diabetes mellitus sebanyak 821, tahun 2017 sebanyak 903, tahun 2018 sebanyak 1.089, dan bulan Januari tahun 2019 terdapat 102 kunjungan pasien diabetes mellitus. Jika dibiarkan terus menerus tanpa ada langkah pencegahan maka prevalensi kejadian diabetes mellitus tidak akan mengalami penurunan. 
Vol. .... No......20....

e-issn : 2622-0148, p-issn : 2087-0035

Kualitas hidup menjadi sangat penting bagi penderita DM karena dengn kualitas hidup yang baik, penderita dapat mengelola penyakit dan menjaga kesehatan lebih maksimal sehingga kesejahteraan hidupnya lebih terjamin. Salah satu aspek yang dapat meningkatkan kualitas hidup penderita adalah dukungan sosial (Mirza, 2017).

Dukungan sosial merupakan informasi lain bahwa individu dicintai, diperhatikan, dihargai, dan dihormati serta menjadi bagian jaringan komunikasi dan kontak yang saling menguntungkan. Bentuk dukungan sosial yang dibutuhkan oleh penderita diabetes mellitus dapat berupa saran, nasehat, kepercayaan, kehangatan, kepedulian, empati, oenghargaan positif, dorongan maju, peserujuan terhadap gagasan dan perasaan, bisa juga berupa dukungan barang atau materil. Melalui cara pandang yang positif, akan menimbulkan keyakinan bahwa dirinya mampu menghadapi berbagai masalah yang dialami (Mirza, 2017).

Menurut Ali dan Mirza (2017) dukungan keluarga dapat meningkatkan kualitas hidup pasien diabetes mellitus. Dukungan ini berupa informasi, tingkat laku tertentu atau materi yang dapat menjadikan individu merasa disayangi, diperhatikan, dan dicintai. Dengan meningkatnya kualitas hidup pasien, secara langsung bertahap akan meningkatkan kepercayaan diri dan lebih kuat dalam menjalani kehidupan dengan penyakit yang diderita.

Dukungan dari keluarga akan memberiukan

rasa nyaman, termotivasi untuk tetap mempertahankan kualitas hidup seperti layaknya individu pada umumnya serta mampu menerima dengan lapang dada kondisi yang dapat membuat penderita lebih kuat. Menurut Yanto \& Setyawati (2017) dukungan keluarga yang baik akan mendukung pelaksanaan program terapi sehingga akan menurunkan kadar gula darah.

Dukungan keluarga dan lingkungan sosial merupakan bagian yang paling penting pada kualitas hidup pasien. Ketika individu mengalami penyakit diabetes mellitus, dukungan keluarga serta lingkungan sosialnya dapat membantu dalam proses adaptasi biologis maupun psikologis yang diharapkan mampu mengurangi tingkat kecemasan dan juga memberikan rasa nyaman dan aman (Jauhari, 2016).

Mengingat pentingnya dukukan sosial dan keluarga terhadap kualitas hidup pasien diabetes mellitus, maka perlu dilakukan konseling dan pendidikan kesehatan kepada pasien serta anggota keluarga. Hal ini dilakukan untuk mengetahui sampai sejauhmana peran lingkungan sosial serta keluarga terhadap dukungan yang diperolehnya, serta lebih banyak melibatkan keluarga dalam pelayanan keperawatan.

Tujuan dari penelitian ini adalahn untuk mengetahui pengaruh dukungan sosial dan keluarga terhadap kualitas hidup pasien DM tipe 2 di wilayah kerja Puskesmas Mangasa Kota Makassar.

\section{METODE \\ Desain, tempat dan waktu}

Desain penelitian yang digunakan dalam penelitian ini adalah descriptive analytic dengan pendekatan cross sectional yang bertujuan untuk mengetahui pengaruh antar variabel dimana variabel independen (dukungan sosial, dukungan keluarga) dan independen (kualitas hidup pasien DM) diidentifikasi pada satuan waktu (Dharma, 2017). Penelitian ini dilaksanakan tanggal 22 April-31 Mei 2019 di wilayah kerja Puskesmas Mangasa Kota Makassar.

\section{Jumlah dan cara pengambilan subjek}

Populasi yang digunakan dalam penelitian ini adalah penderita DM tipe 2 yang ada atau berkunjung di Puskemas Mangasa Kota Makassar pada tahun 2018 yakni sebanyak 294 orang. Adapun sampel dalam peneltian ini adalah pasien diabetes mellitus yang memenuhi kriteria inklusi (kriteria yang layak diteliti) yaitu pasien menderita diabetes mellitus tipe 2 yang aktif dan terdata di Puskesmas Mangasa selama periode Januari-Maret 2019, berusia 40-60 tahun, masih memiliki keluarga, aktif dii lingkungan sosial, dapat membaca dan menulis, serta bersedia menjadi responden.

Penentuan sampel pada penelitian ini menggunakan metode probability sampling yaitu memilih sampel dengan secara acak dengan memberikan peluang yang sama kepada setiap individu dalam populasi untuk menjadi sampel penelitian dengan teknik simple random sampling. Teknik simple random sampling yaitu metode pengambilan sampel secara acak sederhana dengan asumsi bahwa karakteristik tertentu yang dimiliki oleh populasi tidak dipertimbangkan dalam penelitian.

HASIL

Tabel 1

Distribusi Frekuensi Responden Penderita DM Tipe 2 di Wilayah Kerja Puskesmas Mangasa Kota Makassar $(n=56)$

\begin{tabular}{lcc}
\hline \multicolumn{1}{c}{ Variabel } & Frekuensi & $\begin{array}{c}\text { Persentase } \\
\%\end{array}$ \\
\hline $\begin{array}{l}\text { Jenis Kelamin } \\
\text { Laki-laki }\end{array}$ & 17 & 30,4 \\
$\quad$ Perempuan & 39 & 69,6 \\
\hline Umur & & \\
$\quad 40-50$ & 12 & 21,4 \\
$51-60$ & 44 & 78,6 \\
\hline Pekerjaan & & \\
$\quad$ Tidak Bekerja & 14 & 25 \\
Wiraswasta & 13 & 23,2 \\
IRT & 17 & 30,4 \\
\hline
\end{tabular}


Vol. .... No......20....

e-issn : 2622-0148, p-issn : 2087-0035

\begin{tabular}{lcc}
\hline PNS & 10 & 17,9 \\
Pensiun & 2 & 3,6 \\
\hline Pendidikan & & \\
SD & 8 & 14,3 \\
SMP & 9 & 16,1 \\
SMA & 17 & 30,4 \\
PT & 22 & 39,3 \\
\hline Kekuatan & & \\
dukungan & 20 & 35,7 \\
$\quad$ Suami & 10 & 17,9 \\
Istri & 11 & 19,6 \\
Anak & 15 & 26,8 \\
Ayah/lbu & & \\
\hline
\end{tabular}

Berdasarkan tabel. 1 diatas menunjukkan bahwa responden rata-rata berjenis kelamin perempuan sebanyak 39 orang $(30,4 \%)$. Responden rata-rata berusia 51-60 tahun sebanyak 44 orang $(78,6 \%)$. Responden sebagian besar bekerja sebagai IRT sebanyak 17 orang $(30,4 \%)$ dengan tingkat pendidikan PT sebanyak 22 orang $(39,9 \%)$. Responden sebagian besar tinggal bersama suami sebanyak 20 orang $(35,7 \%)$.

Tabel 2

Distribusi Frekuensi Responden Penderita DM

Tipe 2 Berdasarkan Dukungan Sosial di Wilayah Kerja Puskesmas Mangasa Kota Makassar $(n=56)$

\begin{tabular}{ccc}
\hline Dukungan Sosial & Frekuensi & Persentase $(\%)$ \\
\hline Kurang & 17 & $30,4 \%$ \\
Baik & 39 & $69,6 \%$ \\
\hline Total & 56 & 100 \\
\hline
\end{tabular}

Berdasarkan tabel 2, menunjukkan sebagian besar responden dengan dukungan social baik sebanyak 39 responden $(69,6 \%)$, sementara responden dengan dukungan sosial kurang sebanyak 17 responden $(30,4 \%)$

Tabel 3

Distribusi Frekuensi Responden Penderita DM

Tipe 2 Berdasarkan Dukungan Keluarga di Wilayah Kerja Puskesmas Mangasa Kota Makassar $(n=56)$

\begin{tabular}{ccc}
\hline Dukungan Keluarga & Frekuensi & Persentase (\%) \\
\hline Kurang & 19 & $33,9 \%$ \\
Baik & 37 & $66,1 \%$ \\
\hline Total & 56 & 100 \\
\hline
\end{tabular}

Berdasarkan tabel 3 menunjukkan sebagian besar responden dengan dukungan keluarga baik sebanyak 37 responden $(66,1 \%)$,

sementara responden dengan dukungan keluarga kurang sebanyak 19 responden (33,9\%).

Tabel 4

Rata-rata Kualitas Hidup Responden Penderita DM Tipe 2 di Wilayah Kerja Puskesmas Mangasa Kota Makassar $(n=56)$

\begin{tabular}{ccccccc}
\hline & $\mathrm{n}$ & $\min$ & Max & Mean & SD & $95 \% \mathrm{Cl}$ \\
\hline $\begin{array}{c}\text { Kualitas } \\
\text { hidup }\end{array}$ & 56 & 51 & 65 & 58,75 & 4.88 & $57,44-60,06$ \\
\hline
\end{tabular}

Berdasarkan tabel 4 menunjukkan bahwa kualitas hidup responden memiliki nilai rata-rata 58,75 dengan nilai maksimum sebesar 65 dan minimum 51. Hasil analisis lebih lanjut, responden memiliki peluang untuk memiliki kualitas hidup yang baik dibanding kualitas hidup kurang $(95 \% \mathrm{Cl}$;OR 57,44-60,06)

Tabel 5

Pengaruh Dukungan Sosial tKualitas Hidup Responden Penderita DM Tipe 2 di Wilayah Kerja Puskesmas Mangasa Kota Makassar $(n=56)$

\begin{tabular}{ccccccc}
\hline & $\begin{array}{c}\text { Dukunga } \\
\text { n sosial }\end{array}$ & $\mathrm{n}$ & Mean & SD & $\mathrm{P}$ & $95 \% \mathrm{Cl}$ \\
\hline $\begin{array}{c}\text { Kualitas } \\
\text { Hidup }\end{array}$ & $\begin{array}{c}\text { Kurang } \\
\text { Baik }\end{array}$ & 17 & 56.47 & 4.77 & 0.02 & $0,54-6,001$ \\
\hline
\end{tabular}

Berdasarkan tabel 5 menunjukkan rata rata skor pengaruh kualitas hidup terhadap dukungan sosial baik adalah 59,74 dengan standar deviasi 4,64 sedangkan dukungan sosial kurang memiliki rata-rata 56,74 dengan standar deviasi 4,77. Hasil uji statistik didapatkan nilai $p=0,02$. Hasil analisis lebih lanjut, responden memiliki peluang untuk memiliki dukungan sosial yang baik dibanding dukungan sosial kurang $(95 \% \mathrm{Cl} ; \mathrm{OR}$ 0,54-6,001). Maka dapat disimpulkan bahwa, Ada Pengaruh Dukungan Sosial Terhadap Kualitas Hidup Pasien Diabetes Mellitus Tipe 2 di Wilayah Kerja Puskesmas Mangasa Kota Makassar.

Tabel 6

Pengaruh Dukungan Keluarga Terhadap Kualitas Hidup Penderita DM Tipe 2 di Wilayah Kerja

Puskesmas Mangasa Kota Makassar $(n=56)$

\begin{tabular}{lcccccc}
\hline & $\begin{array}{c}\text { Dukungan } \\
\text { keluarga }\end{array}$ & $\mathrm{n}$ & Mean & SD & $\mathrm{p}$ & $95 \% \mathrm{Cl}$ \\
\hline $\begin{array}{c}\text { Kualitas } \\
\text { Hidup }\end{array}$ & Kurang & 19 & 56.47 & 4.75 & 0.01 & $0,82-6,07$ \\
\hline
\end{tabular}

Berdasarkan tabel 6 menunjukkan rata rata skor pengaruh kualitas hidup terhadap dukungan keluarga baik adalah 59,92 dengan standar deviasi 
Vol. .... No......20....

e-issn : 2622-0148, p-issn : 2087-0035

4,57 sedangkan dukungan keluarga kurang memiliki rata-rata 56,47 dengan standar deviasi 4,75. Hasil uji statistik didapatkan nilai $p=0,01$. Hasil analisis lebih lanjut, responden memiliki peluang untuk memiliki dukungan keluarga yang baik dibanding dukungan keluarga yang kurang $(95 \% \mathrm{Cl} ; \mathrm{OR}$ 0,826,07). Maka dapat disimpulkan bahwa, Ada Pengaruh Dukungan Keluarga Terhadap Kualitas Hidup Pasien Diabetes Mellitus Tipe 2 di Wilayah Kerja Puskesmas Mangasa Kota Makassar.

\section{PEMBAHASAN}

\section{Pengaruh dukungan sosial terhadap kualitas hidup}

Kualitas hidup erat hubungannya dengan kesehatan fisik, psikologis serta keyakinan diri sendiri dan hubungan dengan lingkungan. Kesehatan fisik dapat mempengaruhi kualitas hidup dari segi kemampuan individu dalam menjaga pola hidup sehat karena dengan menjaga pola hidup sehat, individu diharapkan tidak mengalami komplikasi dari penyakit DM yang akan memperburuk kondisinya, derajat kesehatannya akan lebih meningkat sehingga kualitas hidup lebih terjamin. Psikologis dapat mempengaruhi kualitas hidup dari segi kemampuan pasien dalam mengelola stress

Tidak mudah bagi individu menerima penyakit DM yang dideritanya selama bertahuntahun, namun dengan sistem koping yang kuat dari dalam diri, serta mendapat dukungan dari orangorang terdekatnya dapat membuat individu menerima dengan ikhlas keadaan yang dialaminya sekarang. Keyakinan diri sendiri dan hubungan dengan lingkungan dapat berpengaruh terhadap kualitas hidup karena individu memiliki keyakinan bahwa ia tidak sendirian, ia memiliki orang-orang yang menyayanginya, memberikan perhatian dan motivasi agar tidak mudah menyerah dalam menjalani kehidupannya saat ini.

Hasil penelitian menunjukkan mayoritas responden mempunyai tingkat pendidikan perguruan tinggi $(39,3 \%)$. Perguruan tinggi merupakan jenjang pendidikan yang sudah sangat tinggi Tingkat pendidikan memiliki pengaruh yang sangat penting bagi kesiapan responden dalam menerima penyakit yang diderita, mengelola penyakit serta berperilaku dalam kehidupan sosial. Pendidikan mempengaruhi responden dalam memilah kegiatan yang harus dilakukan untuk mencapai kualitas hidup yang baik, memilih pengobatan yang terbaik untuk menunjang kesehatannya, mencari informasi akurat dalam mencegah komplikasi agar tidak salah dalam mengambil tindakan yang hanya memperburuk kondisi kesehatannya. Sejalan dengan penelitian yang dilakukan Tamara, dkk (2014) menjelaskan bahwa, seseorang yang memiliki tingkat pendidikan yang tinggi akan lebih dewasa dalam menerima pengaruh positif dan terbuka terhadap informasi terkait kesehatan, sehingga memudahkan dalam melaksanakan manajemen perawatan yang dapat meningkatkan kualitas hidup.

Berdasarkan hasil penelitian yang telah dilakukan, rata-rata kualitas hidup responden yaitu 58,75 . Hal tersebut menunjukkan bahwa kualitas hidup berpengaruh terhadap pengelolaan penyakit sehingga responden dapat menjaga kesehatan lebih maksimal untuk menjamin kesejahteraan hidupnya. Kualitas hidup erat hubungannya dengan kesehatan fisik, psikologis serta keyakinan diri sendiri dan hubungan dengan lingkungan.

Hal ini sesuai dengan hasil penelitian sebelumnya yang dilakukan oleh Erniantin, dkk (2018) di Puskesmas Ngrambe, rata-rata responden komunitas diabetes $(70 \%)$ memiliki kualitas hidup yang baik. Penelitian tersebut menjelaskan bahwa penyakit diabetes perlu pengelolaan secara baik, tepat serta konsisten, yang diharapkan dapat terhindar dari komplikasi agar dapat menjalankan kegiatan sehari sehari. Salah satu faktor penting dalam pengelolaan diabetes yaitu efikasi diri. Dengan adanya efikasi diri, diharapkan individu dapat berusaha menghadapi berbagai tuntutan sosial, psikososial yang dapat berpengaruh terhadap kualitas hidup. Efikasi diri mampu mengendalikan kemajuan kondisi kesehatan individu karena rasa percaya diri dan keyakinannya untuk meningkatkan kualitas hidup.

Berdasarkan hasil penelitian yang telah dilakukan, sebagian besar responden $(69,6 \%)$ memiliki dukungan sosial yang baik. Hal tersebut menunjukkan bahwa dukungan sosial memiliki pengaruh yang signifikan, baik dari segi bimbingan, hubungan yang diandalkan, kelekatan, pengakuan atau penghargaan, integrasi sosial, dan kesempatan memberikan pengasuhan. Ini berarti bahwa lingkungan tempat responden tinggal memberikan dukungan yang baik untuk menghadapi penyakit yang diderita sehingga pasien ikhlas menerima kondisinya saat ini, mampu menambah rasa percaya diri, serta mau menjalankan program pengobatan dengan baik untuk meningkatkan derajat kesehatannya.

Hal ini sesuai dengan penelitian sebelumnya yang dilakukan oleh Jauhari (2016) di RSUD dr. Abdoer Rahem Situbondo, rata-rata responden $(40 \%)$ mendapatkan dukungan sosial yang baik. Penelitian tersebut juga menjelaskan bahwa dukungan sosial memberikan informasi kepada responden bahwa ia merasa dicintai, diperhatikan, dihargai dan dihormati. Informasi yang didapatkan berasal dari pasangan hidup, rekan kerja, teman dan kelompok tertentu. Dukungan sosial memiliki banyak pengaruh terhadap kesehatan melalui pemberian efek dan cara pandang yang 
Vol. .... No......20....

e-issn : 2622-0148, p-issn : 2087-0035

positif kepada penderita. Melalui cara pandang yang positif akan menimbulkan keyakinan bahwa dirinya mampu menghadapi berbagai masalah yang dialami (Mirza, 2017).

Dari hasil analis dengan menggunakan uji statistic Mann-withney didapatkan nilai $p=0,02=(a$ $=0,05)$ menujukkan bahwa terdapat pengaruh yang signifikan antara dukungan sosial dengan kualitas hidup pasien dibetes mellitus tipe 2. Dukungan sosial adalah sebuah penguat positif yang didapatkan individu dari orang-orang disekitarnya yang diharapkan dapat meningkatkan kualitas hidup untuk mencapai kesembuhan yang optimal. Dukungan sosial yang langsung diterima oleh individu dapat membuat ia merasa diperhatikan, hal ini dapat menjadi salah satu cara agar individu memiliki semangat untuk menjalani pengobatan secara maksimal.

Dukungan sosial merupakan salah satu faktor yang dapat mempengaruhi kualitas hidup seseorang. Kualitas hidup yang baik menunjukkan bahwa seseorang telah memiliki dukungan sosial yang tinggi. Hasil ini sejalan dengan penelitian yang dilakukan oleh Ismail (2016) yang menyatakan bahwa terdapat hubungan kelompok terhadap kualitas hidup penderita DM di Persadia Cabang Surakarta. Individu yang aktif terlibat dalam kelompok ini terbuka dalam pemberian informasi baru ataupun pendapatnya mengenai problem yang tengah dihadapinya. Hal tersebut menjadikan kualitas hidup individu menjadi lebih baik dan diharapkan akan selalu meningkat.

Penelitian tersebut didukung oleh teori dari Lin, dkk dalam Pratiwi (2015) yang menyatakan bahwa jaringan sosial memiliki efek potensial pada kemampuan berorganisasi dalam lingkungan masyarakat sehingga dapat membantu dalam menyelesaikan masalah yang sedang dihadapi. Hal tersebut memberikan timbal balik sosial yang stabil dan pengalaman emosional yang positif, seperti rasa aman dan sense of belonging (rasa memiliki) sehingga mampu meningkatkan kualitas hidup.

Dukungan sosial dalam kelompok yang diterima oleh responden diperoleh dari keterlibatannya dalam sebuah kelompok. Responden yang ikut andil dalam pertukaran informasi dan pembuatan keputusan mengenai kesehatannya dapat meningkat kualitas hidupnya, ini dikarenakan responden merasa tidak ada ada hambatan atas penyakit diabetes yang dideritanya. Adanya dukungan kelompok dalam hal pemberian dukungan emosional seperti empati kepada anggota lain jika ia sakit akan memberikan motivasi sehingga meningkatkan rasa percaya diri untuk lekas sembuh. Individu yang aktif dalam kegiatan kelompok akan mendapatkan dukungan serta dorongan untuk melakukan sebuah perubahan positif pada kesehariannya sehingga kualitas hidup dapat meningkat.

Dukungan sosial baik yang diberikan kepada individu dapat menurunkan stress emosional sehingga dapat meningkatkan kualitas hidupnya. Dukungan sosial dapat bermanfaat karena individu mengetahui jika banyak orang lain yang selalu memberikan perhatian serta menghargainya, hal ini membuat peningkatan kepandaian akal sehingga mampu beradaptasi dalam kehidupan penderita DM dan dapat menurunkan stress emosional dalam menjalankan pengobatan untuk meningkatkan derajat kualitas hidup.

Menurut hasil penelitian yang dilakukan oleh Rennata dan Kus (2016) menunjukkan hasil ada hubungan antara dukungan sosial dengan stress emosional diabetisi. Dukungan sosial berkaitan erat dengan kondisi psikologi, dukungan sosial yang diberikan dalam bentuk penghargaan dan penilaian diharapkan mampu untuk mengenal masalah kesehatan dan perubahan yang terjadi pada responden sehingga mampu meningkatkan kualitas kesehatan. Hasil penelitian tersebut didukung oleh teori Walker dalam Syahrir (2016) yang menjelaskan bahwa dukungan sosial dapat memberikan manfaat yang positif terhadap stress, dukungan ini ditujukan untuk membantu dalam memecahkan sebuah problem serta kontrol pribadi yang sangat menguntungkan. Hal tersebut dapat mempengaruhi kualitas hidup

\section{Pengaruh dukungan keluarga terhadap kualitas hidup \\ Kualitas hidup merupakan hal-hal yang} dirasakan individu dalam kehidupan sehari-hari dinilai dari kesejahteraan hidup yang sesuai dengan keadaan lingkungan sekitar tempat tinggalnya. Kualitas hidup individu dapat dilihat dari kemampuannya dalam melakukan berbagai perilaku perawatan diri. Seseorang yang memiliki penyakit diabetes mellitus dapat membuat kualitas hidupnya menurun, maka dari itu dibutuhkannya kontrol glikemik yang maksimal. Beberapa faktor psikososial seperti dukungan keluarga, perencanaan dalam menghadapi kemungkinan masalah yang akan datang, serta pribadi yang kuat secara langsung akan mengubah kualitas yang buruk menjadi lebih baik atau meningkat, meskipun proses perubahannya membutuhkan waktu yang lumayan lama. Hasil dari segala tindakan perawatan yang dilakukan merupakan merupakan tujuan akhir dari kualitas hidup.

Berdasarkan hasil penelitian yang dilakukan oleh Ratnawati (2016) menyatakan bahwa rata-rata nilai kualitas hidup responden adalah 3,89 $(S D=0,22)$, hal ini menunjukkan bahwa responden memiliki kualitas hidup yang baik dari segi fisik, psikologis, maupun sosial. Dengan kualitas hidup 
Vol. .... No......20....

e-issn : 2622-0148, p-issn : 2087-0035

yang baik, individu dianggap sudah mampu memecahkan masalah, lebih siap dalam penangangan tekanan hidup serta berpotensi untuk meningkatkan management diri dari segi perubahan tingkah laku dengan strategi terapeutik.

Hasil penelitian didapatkan bahwa sebagian besar responden $(66,1 \%)$ memiliki dukungan keluarga yang baik. Hal tersebut menunjukkan bahwa keluarga merupakan sumber psikologis yang kuat dan sangat penting bagi pengobatan responden. Dukungan yang diberikan kepada individu otomatis akan meningkatkan kepercayaan diri dan akan lebih survive dalam menjalani kehidupan dengan penyakit yang diderita. Dukungan dari keluarga akan memberikan rasa nyaman, dan termotivasi untuk tetap mempertahankan kualitas hidup seperti layaknya individu pada umumnya serta mampu menerima dengan lapang dada kondisi yang dapat membuat responden lebih kuat.

Hal diatas sejalan dengan penelitian yang dilakukan oleh Nuraisyah, et al (2017) yang menyatakan bahwa dukungan keluarga yang diberikan kepada anggota keluarga lainnya yang menderita DM Tipe 2 memiliki peran yang sangat penting pada penatalaksanaan pengobatan diabetes. Individu tidak merasa terbebani oleh penyakit diabetes melainkan bersemangat dalam menjalankan kegiatan sehari-hari pada umumnya karena memiliki dukungan dari anggota keluarganya. Hal tersebut akan menghasilkan kualitas hidup pasien DM Tipe 2 yang baik.

Hasil penelitian yang dilakukan menunjukkan adanya kekuatan dukungan yang paling kuat diperoleh responden dari suami $(35,7 \%)$. Kedekatan hubungan suami dan istri akan memberikan kekuatan yang positif, karena seseorang akan mendaptkan perhatian dari pasangannya yang dapat meningkatkan semangat dalam menjalani pengobatan walau seberat apapun penyakit yang diderita. Adanya dukungan dari seorang suami membuat sistem koping menjadi adekuat, karena suami akan lebih sering mendengarkan keluh kesah pasangannya, memberikan solusi dan motivasi sehingga istri merasa dipedulikan, disayangi, dicintai, meminimalkan perasaan stress yang dirasakan seorang istri untuk menjadikan kualitas hidup lebih baik.

Hal tersebut sejalan dengan penelitian yang dilakukan oleh Kodrati dalam Tamara (2014) yang menyatakan bahwa suatu pernikahan memberikan keuntungan terhadap kesehatan individu karena akan mendapatkan perhatian dari pasangannya.

Dari hasil analis dengan menggunakan uji statistic Mann-withney didapatkan nilai $p=0,01=(a$ $=0,05$ ) menujukkan bahwa terdapat pengaruh yang signifikan antara dukungan keluarga dengan kualitas hidup pasien dibetes mellitus tipe 2. Dukungan keluarga merupakan dukungan yang diberikan oleh orang terdekat pasien seperti orang tua, suami, istri, atau anak yang bukan hanya sekedar perhatian akan kebutuhan fisik saja, namun kebutuhan psikologi serta bagaimana pemahaman keluarga terhadap penyakit yang diderita oleh anggota keluarga lainnya. Dukungan keluarga dapat menjadikan individu merasa disayangi, diperhatikan dan dicintai.

$\mathrm{Hal}$ ini sejalan dengan penelitian yang dilakukan oleh Rahmawati, et al (2014) yang menunjukkan bahwa dukungan keluarga memberikan pengaruh terhadap kualitas hidup, hal ini disebabkan karena keluarga merupakan faktor penguat kedua setelah diri pribadi. Keluarga dapat memberikan perhatian dan motivasi untuk dapat melakukan kegiatan yang bermanfaat sehingga pasien tidak mudah menyerah terhadap penyakit yang sedang diderita, sehingga kualitas hidup dapat meningkat. Kualitas hidup yang meningkat membuktikan bahwa pasien memiliki dukungan keluarga yang tinggi.

Dukungan keluarga mempengaruhi sikap pasien DM dalam menerima atau menolak mempelajari DM selama menjalani pengobatan. Pasien DM akan lebih bersikap positif untuk menjalankan program pengobatan jika mendapatkan dukungan keluargan yang positif namun ketika pasien menolak atau bersikap negatif terhadap mengobatan yang programkan, akan berimbas pada kegagalan penatalaksanaan DM secara terapiutik sehingga mempengaruhi kualitas hidup pasien.

Pernyataan dalam penelitan yang dilakukan oleh Tamara, et al (2014) yang menunjukkan bahwa ada hubungan antara dukungan keluarga dengan kualitas hidup pasien DM Tipe 2. Hal ini membuktikan bahwa dukungan yang diterima dari keluarga salah satunya berupa dorongan untuk selalu mengontrol kesehatannya ke rumah sakit atau puskesmas atau membantu pasien dalam usahanya melakukan perawatan mandiri terkait dengan penyakit DM yang diderita seperti diet, keteraturan minum obat, penggunaan insulin yang dapat menurunkan kadar gula darah. Dukungan keluarga semacam ini menjadi salah satu bagian dalam meningkatkan kualitas hidup pasien DM Tipe 2.

Pernyataan tersebut sejalan dengan teori yang menyatakan bahwa agar keluarga menjadi sumber kesehatan primer dan efektif, mereka harus menjadi lebih terlibat dalam tim perawatan kesehatan dan proses terapi total. Agar responden terlibat dalam perawatan diri yang efektif, mereka harus memiliki pengetahuan dan keterampilan yang diperlukan untuk memberikan perawatan kesehatan yang baik. Hal ini berarti bahwa keluarga perlu akses ke sumber informasi kesehatan primer dengan memasukkan pendidikan kesehatan yang ditujukan 
Vol. .... No......20....

e-issn : 2622-0148, p-issn : 2087-0035

untuk perawatan mandiri dan pemberdayaan keluarga sehingga dapat meningkatkan kualitas hidup (Krozy, 1996; Levine, dkk, 2000 dalam Friedman, dkk, 2018). Namun ada hal-hal yang dapat menurunkan kualitas hidup penderita DM yaitu, faktor umur yang semakin tua sehingga menurunkan kemampuan dalam melakukan kegiatan sehari-hari atau karena penyakit yang sudah bertahun tahun diderita sehingga menimbulkan komplikasi seperti menurunnya sistem penginderaan, hipertensi serta penyakit jantung kronik.

Penelitian mulitivariat yang dilakukan oleh Nuraisyah, et al (2017) menunjukkan adanya hubungan yang bermakna secara statistik antara dukungan keluarga dengan kualitas hidup. Dukungan keluarga menjadi salah satu aspek penting yang dapat mempengaruhi kondisi kesehatan psikologis dan sosial. Kehangatan dan keramahan pada dukungan emosional mampu meningkatkan efikasi diri sehingga mendukung keberhasilan dalam perawatan diri yang baik untuk menghasilkan kualitas hidup yang baik.

\section{KESIMPULAN}

Berdasarkan hasil analisis dan pembahasan di atas maka dapat merumuskan kesimpulan sebagai berikut :

1. Dukungan sosial pasien diabetes mellitus tipe 2 di wilayah kerja Puskesmas Mangasa Kota Makassar memiliki dukungan sosial yang baik. Ada pengaruh dukungan sosial terhadap kualitas hidup pasien diabetes mellitus tipe 2 di wilayah kerja Puskesmas Mangasa Kota Makassar.

2. Dukungan keluarga pasien diabetes mellitus tipe 2 di wilayah kerja Puskesmas Mangasa Kota
Makassar memiliki dukungan keluarga yang baik. Ada pengaruh dukungan keluarga terhadap kualitas hidup pasien diabetes mellitus tipe 2 di wilayah kerja Puskesmas Mangasa Kota Makassar.

\section{SARAN}

Berdasarkan hasil penelitian, maka dapat diberikan beberapa saran kepada pihak yang terkait anatara lain :

1. Bagi keluarga dan lingkungan sosial diharapkan dapat menjadi sumber informasi dan penguat penderita DM dalam menjalankan pengobatan yang optimal.

2. Bagi pimpinan Puskesmas Mangasa diharapkan dapat meningkatkan pelayanan konseling dari petugas puskesmas kepada pasien tentang pengaruh dukungan sosial dan keluarga terhadap kualitas hidup khususnya penderita DM.

3. Bagi institusi pendidikan kesehatan diharapkan dapat dijadikan bahan ajar dosen pada mata kuliah keperawatan komunitas

4. Bagi peneliti selanjutnya khususnya profesi perawat yang tertarik meneliti variabel yang sama agar meneliti manakah dari anggota keluarga yang memiliki dukungan sangat kuat terhadap kualitas hidup penderita diabetes mellitus tipe 2

\section{UCAPAN TERIMA KASIH}

Ucapan terima kasih diampaikan kepada semua pihak yang telah membantu dalam penyelesaian penelitian ini.

\section{DAFTAR PUSTAKA}

Dinas Kesehatan Pemerintah Kota Makassar. 2015. Profil Kesehatan Kota Makassar. [onlie]. Dari:(file://ID:/DM/survey/Profil\%20Kesehatan\%20Kota\%20Makassar\%20Tahun\%202015.pdf). Diunduh 10 Januari 2019

Dharma, K. K. (2017). Metodologi Penelitian Keperawatan: Panduan Melaksanakan dan Menerapkan Hasil Penelitian. Jakarta Timur: TIM.

Erniantin, D., Martini, Udiyono, A., \& Saraswati, L. D. (2018). Gambaran Kualitas Hidup Penderita Diabetes Mellitus pada Anggota dan Non Anggota Komunitas Diabetes di Puskesmas Ngrambe. Jurnal Kesehatan Masyarakat, 6.

Friedman, M. M., Bowden, V. R., \& Jones, E. G. (2018). Buku Ajar Keperawatan Keluarga: Riset, Teori, \& Praktik. Jakarta: EGC.

Ismail, M. H. (2016). Pengaruh Dukungan Kelompok Terhadap Kualitas Hidup Penderita Diabetes Mellitus di Persadia Cabang Surakarta.

Jauhari. (2016). Dukungan Sosial dan Kecemasan pada Pasien Diabetes Melitus. The Indonesian Journal of Health Science, 7(1), 64-76

Kemenkes RI, 2014. Infodatin Diabetes: Pusat data dan informasi Kemenkes RI.[onlie]Dari:http://www.depkes.go.id/download.php?file=download/pusdatin/infodatin-diabetes. Diunduh 6 Juli 2019.

Mirza, R. (2017). Memaksimalkan Dukungan Keluarga Guna Meningkatkan Kualitas Hidup Pasien Diabetes Mellitus. Jurnal JUMANTIK, 2, 12-30. 
Nuraisyah, F., Kusnanto, H., \& Rahayujati, T. B. (2017). Dukungan Keluarga dan kKualitas Hidup Pasien Diabetes Mellitus. Journal of Community Medicine and Public Health, (November 2015).

Pratiwi, Y. (2015). Pengaruh Dukungan Sosial Terhadap Kualitas Hidup Lanjut Usia di Pusat Santunan Keluarga (PUSAKA) Kecamatan Pancoran Jakarta Selatan. Jakarta: UIN Syarif Hidayatullah.

Rahmawati, F., Setiawan, E. P., \& Solehati, T. (2014). Pengaruh Dukungan Keluarga Terhadap Kualitas Hidup Pasien Diabetes Mellitus Tipe 2, 2.

Ratnawati, Novia. (2016). Hubungan Efikasi Diri Terhadap Kualitas Hidup Pasien Diabetes Mellitus Tipe 2 di RS PKU Muhammadiyah Yogyakarta. Yogyakarta: Universitas Muhammadiyah Yogyakarta.

Rennata, R. A., \& Kusumaningrun, N. S. D. (2016). Hubungan Antara Dukungan Sosial Keluarga dan Stres Emosional di Persatuan Diabetes Indonesia (PERSADIA) Unit Rumah Sakit Panti Wilasa Citarum Semarang, 87-93.

Syahrir, H. (2016). Hubungan Dukungan Sosial Keluarga dengan Tingkat Stres pada Penderita Diabetes Mellitus Tipe 2 di Wilayah Kerja Puskesmas Kassi-Kassi Kota Makassar Tahun 2016. Makassar: UIN Alauddin Makassar.

Tamara, E., Bayhakki, \& Nauli, F. A. (2014). Hubungan Antara Dukungan Keluarga dan Kualitas Hidup Pasien Diabetes Mellitus Tipe 2 di RSUD Arifin Achmad Provinsi Riau, 1, 1-7.

WHO, 2016. Diabetes Fakta dan Angka.[online]. Dari:www.searo.who.int/Indonesia/topics.8. Diakses 6 Januari 2019.

Yanto, A., \& Setyawati, D. (2017). Dukungan Keluarga pada Pasien Diabetes Mellitus Tipe 2 di Kota Semarang, (September), 45-49. 